\title{
The Unforgotten Sisters
}

Female Astronomers and Scientists before Caroline Herschel 
More information about this series at http://www.springer.com/series/4097 


\section{The Unforgotten Sisters}

Female Astronomers and Scientists before Caroline Herschel

Springer

Published in association with

Praxis Publishing

Chichester, UK

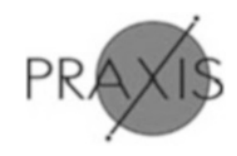


Gabriella Bernardi

Torino, Italy

\section{SPRINGER PRAXIS BOOKS IN POPULAR ASTRONOMY}

\section{Springer Praxis Books}

ISBN 978-3-319-26125-6

DOI 10.1007/978-3-319-26127-0

\section{Library of Congress Control Number: 2016932888}

\section{Springer Cham Heidelberg New York Dordrecht London}

(C) Springer International Publishing Switzerland 2016

This work is subject to copyright. All rights are reserved by the Publisher, whether the whole or part of the material is concerned, specifically the rights of translation, reprinting, reuse of illustrations, recitation, broadcasting, reproduction on microfilms or in any other physical way, and transmission or information storage and retrieval, electronic adaptation, computer software, or by similar or dissimilar methodology now known or hereafter developed.

The use of general descriptive names, registered names, trademarks, service marks, etc. in this publication does not imply, even in the absence of a specific statement, that such names are exempt from the relevant protective laws and regulations and therefore free for general use.

The publisher, the authors and the editors are safe to assume that the advice and information in this book are believed to be true and accurate at the date of publication. Neither the publisher nor the authors or the editors give a warranty, express or implied, with respect to the material contained herein or for any errors or omissions that may have been made.

\section{Cover design: Jim Wilkie}

Printed on acid-free paper

Springer International Publishing AG Switzerland is part of Springer Science+Business Media (www.springer.com) 
To all curious and persevering minds 



\section{Introduction}

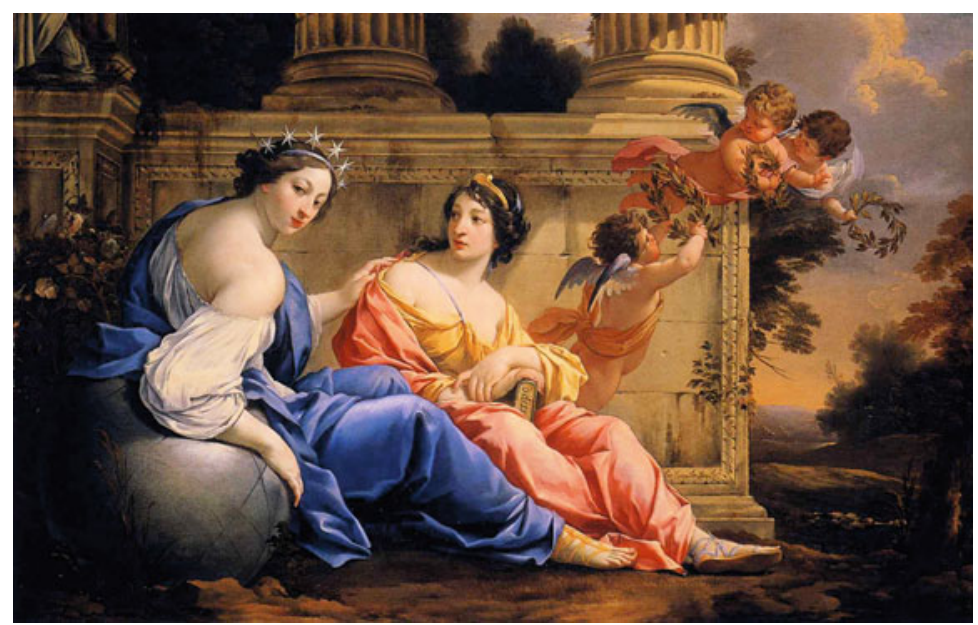

The Muses Urania and Calliope by Simon Vouet approximately 1634

March 4, 1845.

MY DEAREST NIECE, -

Have I understood you alright? Saw you the thermometer $11^{1} 2^{\circ}$ above zero? the lowest I have heard of here was only $13^{\circ}$ below freezing; but we are buried in snow!

March 5th. - No alteration in the weather, nor in my affection for my dear niece and nephew and their ten children! the first is as cold as the latter is warm!

April 29, 1845.

In his father's library my nephew must have found a folio volume of $\mathrm{H}-$ (an astronomer and copper engraver), where, for every hour a distinct picture [of the 
moon] is given. In the Phil. Transactions for 1780 , p. 507, is the first paper of William Herschel on the Moon. In 1787; 1792, p. 27; 1793, p. 206, measure of mountains, \&c.

Twenty-three years ago, when first I came here, I visited Madame W. (not von) once or twice, saw her observatory and a telescope, I believe not above 24-inch focal length; at that time she amused herself with modelling the heads of the Roman Emperors: her daughter, then a girl, was a poet, and a portrait of her was exhibited as a Sappho crowned with laurels....

These lines are part of the correspondence between a famous astronomer who lived at the turn of the eighteenth and nineteenth centuries, Caroline Herschel and her niece-in-law, Margaret Brodie Stewart, wife of the astronomer John Herschel, son of her brother William.

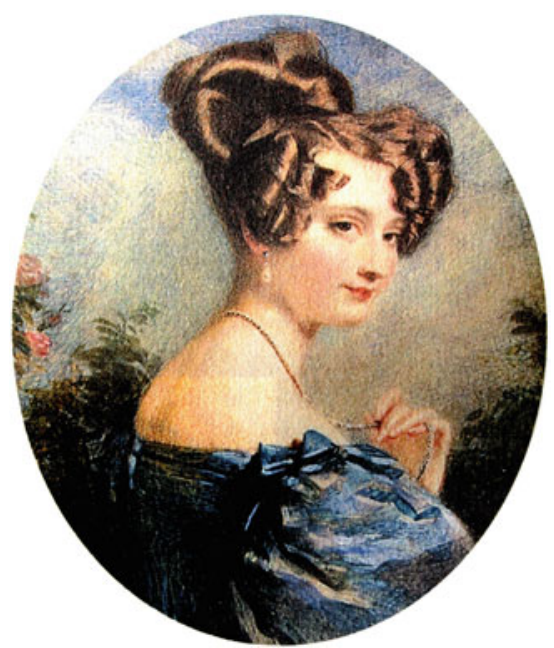

Margaret Herschel (Margaret Brodie Stewart) (1810-1864) wife of the astronomer John Herschel, by Alfred Edward Chalon 1829

Caroline Lucretia Herschel (1750-1848) was probably the most famous female astronomer of the past. Her brother, William, became famous for the discovery of Uranus, and together they pioneered a study of the "physical sky," dealing with a background of stars that until then had been considered little more than a stage in witnessing the motions of the planets. They initiated the study of the interstellar cloud, those regions apparently devoid of stars that we now know to be huge regions of space filled with dust that hide the objects behind them, and they investigated the distribution of the stars in space, attempting for the first time to reconstruct the shape of our Galaxy. 


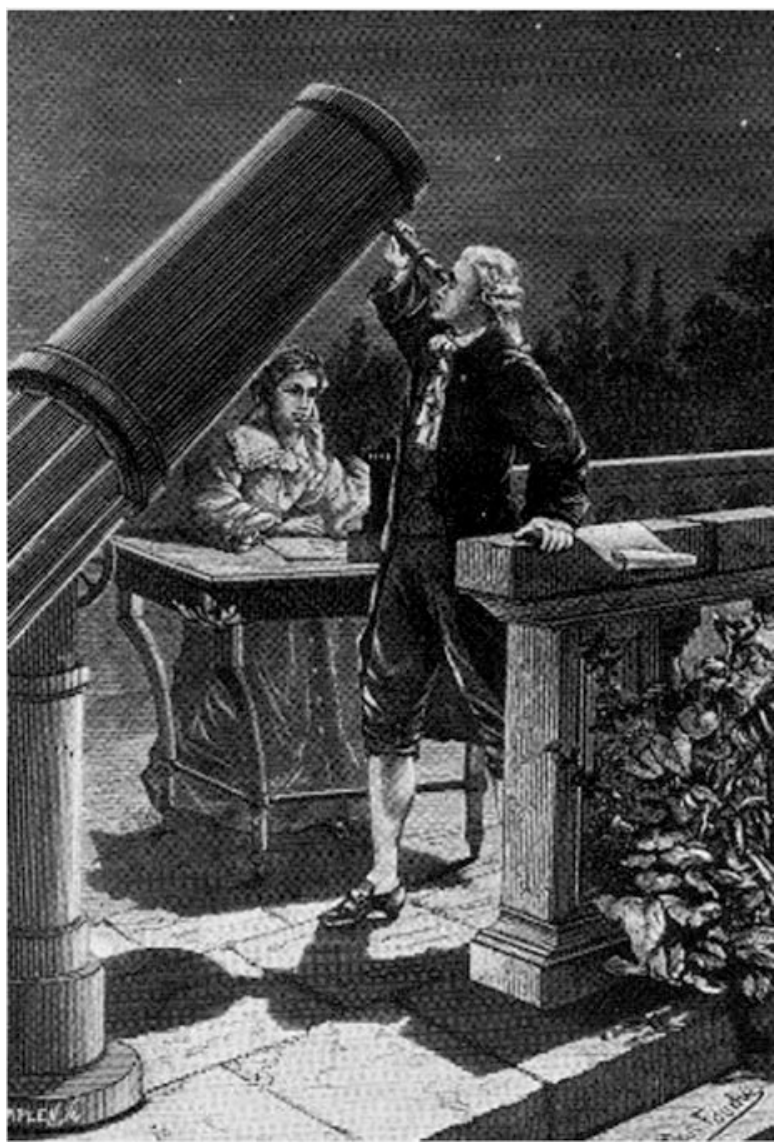

Artist impression of Caroline Herschel taking notes as her brother William observes on March 13, 1781, the Night William Discovered Uranus

Among Caroline's correspondence, the above letter is surely not the most important one from the astronomical point of view, but quite interestingly it is one of the very few, possibly the only one, where she mentions another female astronomer, although probably just an amateur one. It is known, however, that Caroline Herschel was not the only female astronomer of the past deserving an appropriate recognition. The feeling of such lack of appreciation is well portrayed in an intense poem by Siv Cedering (1939-2007) entitled "Letter from Caroline Herschel (1750-1848)" where the artist imagines that the famous astronomer is writing a letter telling her about the demanding work with their brother, that involved both telescope construction and night observations, and how it was difficult to find some time for her personal researches. The conclusion betrays her resigned fear of being forgotten, like the five "long lost sisters" of the past she cites: 
Aganice of Thessaly, Hypatia, Hildegard, Catherina Hevelius and Maria Agnesi, all of them female scientists and astronomers.

It is satisfying to imagine that this letter is addressed to Mary Somerville, another female astronomer and her contemporary, who went down in history with Caroline not only for their contributions to astronomy, but also for being the first women whose scientific merits received a high academic recognition in the form of honorary memberships of the Royal Astronomical Society.

Actually, despite the many difficulties caused by living and working in a maledominated world, a remarkable number of women scientists who brought important contributions to the development of science can be accounted. The story hands down to us the names of at least twenty famous scientists of antiquity, among which that of Hypatia is probably the best known.

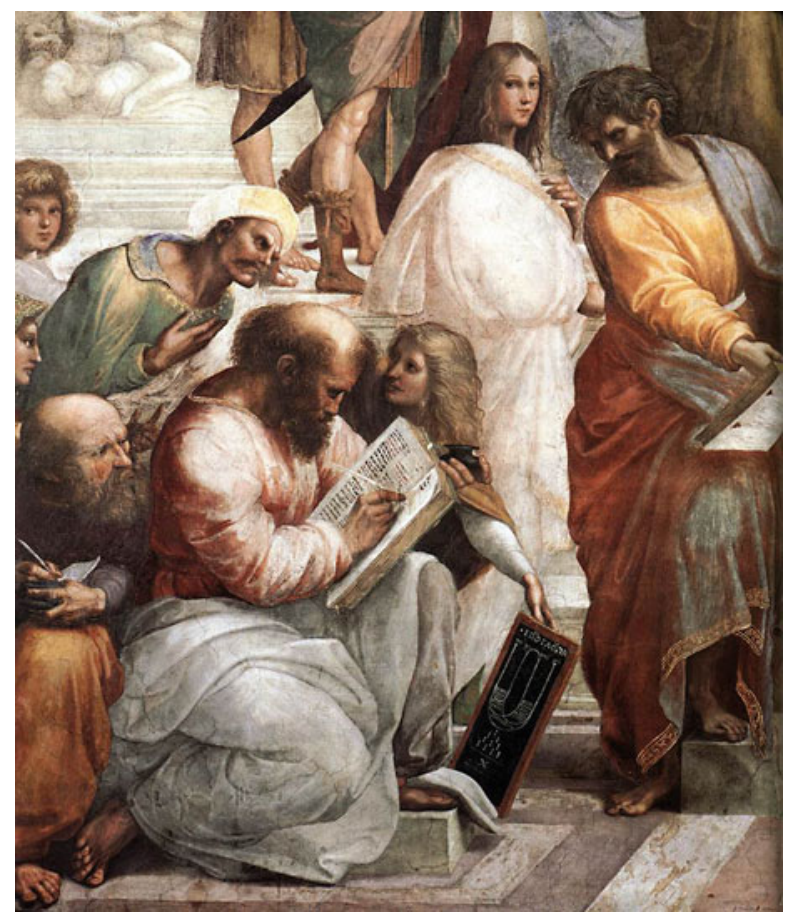

Detail from The School of Athens (1509-1510) by Raffaello Sanzio. It may be a portrait of Francesco Maria della Rovere, or possibly the philosopher Pico della Mirandola. Although with little support, it has also suggested that it might also represent Hypatia

We can find only a dozen of them in the Middle Ages, especially in convents, but almost none between 1400 and 1500. The counting starts to become more precise afterwards, with 16 in the seventeenth century, 24 in the eighteenth century, and 108 in the nineteenth century, while currently about 2000 women are professionally involved in the field of astronomy alone, as reported at the International Astronomical Union General Assembly of 2015. (Actually, among the 11,273 members of 
this organization 1792 are women, i.e. about $15.9 \%$ of the total number.). But how many of them are cited in textbooks?

Indeed, there are no clues of similar acknowledgments to other female figures before Caroline Herschel and Mary Somerville, and unfortunately the history of women in culture, as well as in civilian life, is one of exclusion up to the end of the nineteenth century and still largely up to the middle of the twentieth century. That is at least in industrialized countries, since in many developing nations, with rare exceptions, women are still far from achieving even their most basic rights as human beings. This book will not deal with the causes of this situation, rather it will describe the lives of these distinguished scientists and their achievements in science. Not without difficulty, they undertook mathematical and astronomical studies at a professional level, sometimes leaving an indelible mark in the history of science, despite the obstacles mainly due to the ideas and preconceptions that society placed on them and not on their male counterparts. Indeed, for centuries those women who had access to education were highly placed and lived in monasteries, where actually a fair dowry was required. In other historical periods those few women, favored by having a father, a brother or a husband scientist willing to share their knowledge, could acquire a scientific education, but still in the early twentieth century, in many European countries, girls were denied access to universities and also to high school. Consequently, since women were excluded from universities and from a regular scientific education, there emerged only a few rare cases where they were given a chance, giving rise to the notion that women are not suited to scientific subjects. 



\section{The Three Rs}

This book tells the life stories of 25 female scientists, mainly astronomers and mathematicians, who made very important contributions to the development of science, yet for too long remained forgotten. For each of these "long lost sisters of science", to use Caroline Herschel's phrase in the poem dedicated to her, the author has organized a form of personal file that places each subject's life within its historical context, outlines her main works, highlights some curious and interesting facts, and presents comments from contemporaries and descendants. The book reaches back more than 4000 years, to En HeduAnna, the Akkadian princess, who was one of the first recognized female astronomers, and includes such luminaries as Hypatia of Alexandra, Hildegard of Bingen, Elisabetha Hevelius, and Maria Gaetana Agnesi, through to Mary Somerville and Caroline Herschel herself. The book will be of interest to all who wish to learn more about the women from antiquity to the nineteenth century who played such key roles in the history of astronomy and science despite living and working in largely male-dominated worlds.

Approaching scientific disciplines, and in particularly those related to astronomy, cannot be attempted without some basic knowledge. In this sense the first two of the "three Rs," that is how to read and write, is not enough, and the third one has the most prominent role. This has to be intended in a sense broader than the original one. Indeed, one has to juggle in a mathematical universe made of arithmetic, algebra, geometry, angles and equations of all kinds. Without a proper education it is impossible to move up in this world, so being excluded from knowledge's distribution channel meant to be cut off from certain areas. For centuries, the transmission of knowledge happened through circuits which were quite different from those we currently consider the normality. There was nothing like a minimum level guaranteed to everybody by some public institution. Education, until the nineteenth century, was basically a private burden that could be supported only by families that had both economical means and thirst for knowledge. Education was therefore a privilege usually reserved to the higher social classes. In addition, the kind of education one could receive, and thus win eventual access to the 
scientific community, depended on the cultural preparation and the social position occupied in the civil community. This situation would be enough to understand why so few women are remembered in the history of science.

To give an example, for a long time women were denied access to any University, and an opening occurred for the first time in Europe in 1867 at the Ecole Polytechnique of Zurich. Before then, only Italian Universities had awarded academic titles to some women considered as special, such as the Venetian noblewoman Elena Lucrezia Cornaro Piscopia, who was the first woman in the world to get a master's degree in Philosophy from the University of Padua in 1678.

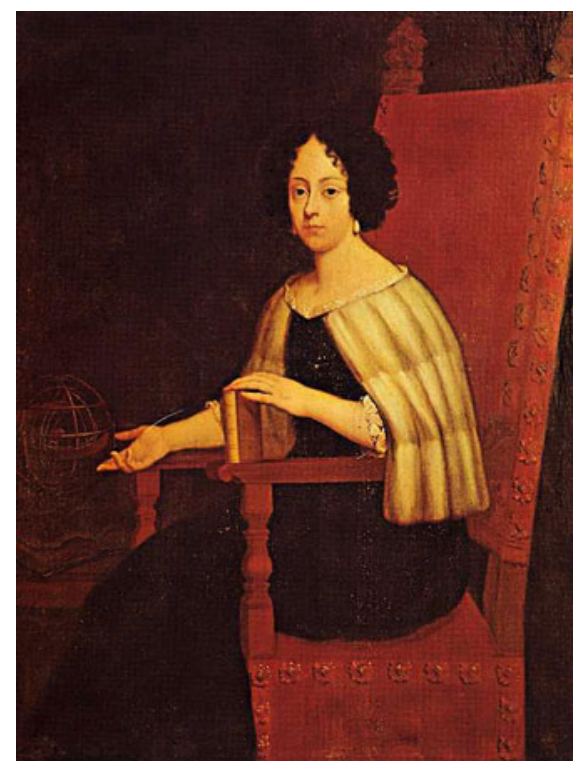

Portrait of Elena Lucrezia Cornaro Piscopia, first women graduate in the world

Despite these difficulties, there have always existed women scholars who worked in scientific disciplines, if they were just given a minimum of freedom and power to access the necessary studies. For centuries, however, they were mere exceptions, and moreover their names have been erased from history. In almost all circumstances they were daughters, wives or sisters of scientists, and their contributions were often confused with their male relatives. 


\section{Presence of astronomers in the family within the book sample}

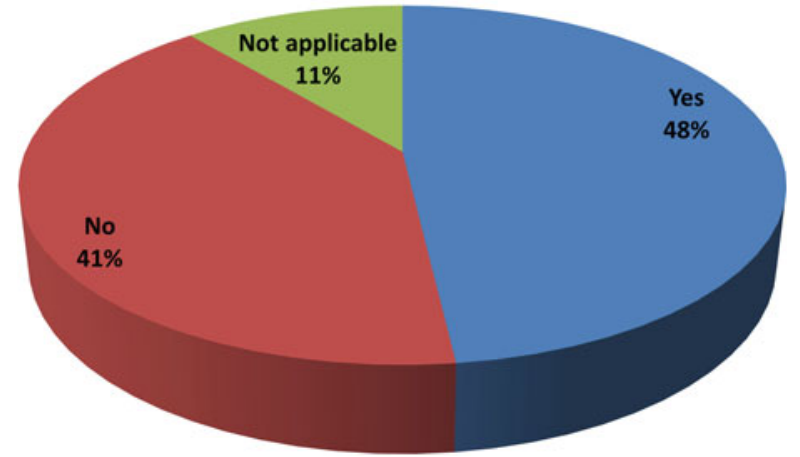

In some cases, where it was possible, they also devised methods to be taken into consideration by publishing under a pseudonym. The most famous example is that of the mathematician Sophie Germain who, during the nineteenth century, signed herself as "Monsieur Le Blanc" in order to communicate with the community of mathematicians such as the celebrated Louis Lagrange.

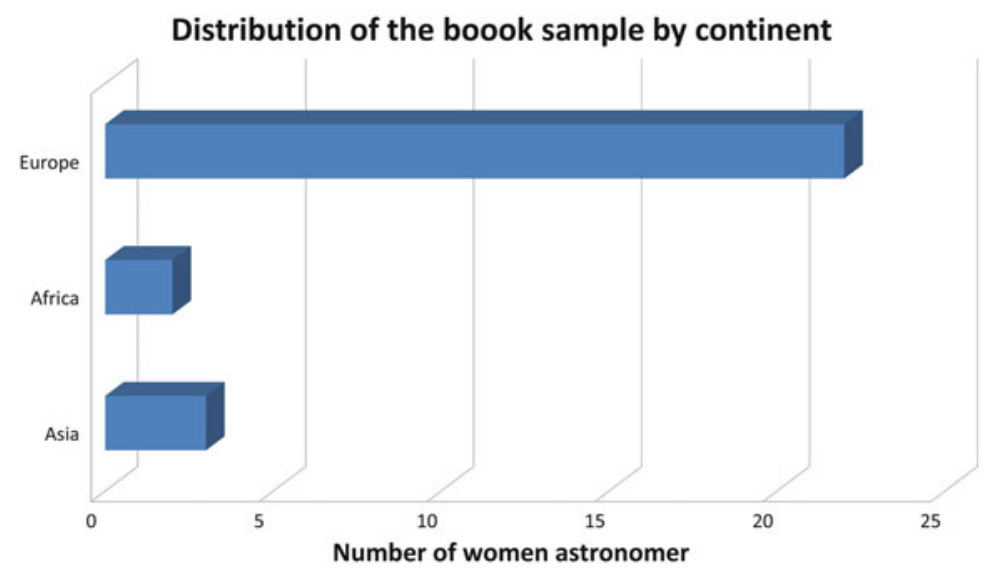

The aim of this research was to describe the lives and the works of the most notable astronomers of the past. They lived mainly in the European-Mediterranean basin, from antiquity to the eighteenth century, until a period ideally represented by Caroline Herschel at a time in which the idea of a more public role of women in Astronomy started to take its first steps. 


\section{Distribution of the book sample by historical period}

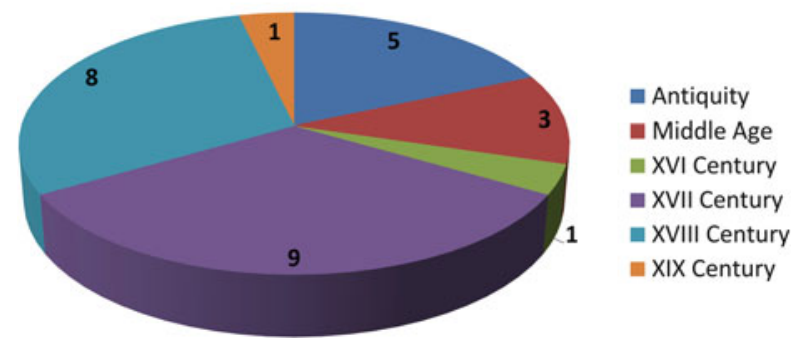

These women undertook their mathematical and astronomical studies at a professional level, distinguishing themselves, not without difficulty, often leaving important contributions to the history of science, despite the many obstacles created by the ideas and preconceptions that society burdened them with in contrast to the advantages of their fellow men.

It was interesting to learn more about the family relationships of some of these scientists and to analyze their influence on the personalities and scientific contributions of these researchers. Often a link was created by some mutual interest between father and daughter, husband and wife or brother and sister, and these strong emotional ties with a prominent but friendly male figure affected the life and the scientific interests of these women who would otherwise not have been able to develop on their own.

We are quite used to this kind of separation of roles between men and women that, among other avocations, reserved the study of natural sciences to the male part of society. This ethos can be dated back to such ancient times that, to modern eyes, female involvement in these subjects appears to be a novelty of our own times. It is known, however, that in antiquity there existed matriarchal societies in which female deities were worshipped in the belief that they were responsible for creation. These societies gradually disappeared, at least in the Mediterranean basin, in favor of prevailing cultures in which religion attributed the creation of life and the universe to an exclusively male principle. It might then be that the study of nature was different in the past, and that women could have taken part in it even as it began a natural removal of themselves from these activities. It might also be that the ancient priestesses of the Mesopotamian and Egyptian civilizations, of which some examples are cited in this book, can be interpreted as the last traces of these ancient roles, which went preserved for some time thanks to some kind of religious legacy.

Such figures probably became less and less common with the evolution of more "modern" societies, but despite the increasing obstacles women had surely to meet, in particular for their participation in scientific knowledge, female contributions never came to an end. Even in the strongly misogynist Greek society we can find some of them back in the seventh and sixth century BC. They flourished within the Pythagorean school, which admitted also women as disciples, among whom the most famous name is that of Teano. Philosopher, mathematician, astronomer and 
physician, she is credited with a prominent role in this school and of several works in these disciplines, but the available information is extremely uncertain because of the sectarian character of this organization and of the secrecy imposed on its followers. Not even her degree of kinship with Pythagoras can be clearly established: she could have been his wife, but in other sources she is attested as his daughter. In any case, such a relationship allowed her to study and to became a scientist who could succeed Pythagoras himself in the direction of his sect in the sixth century BC.

Among the other figures analyzed in this essay, one of the most famous of antiquity is Hypatia of Alexandria, who lived between the fourth and the fifth centuries AD. She was a mathematician, astronomer and philosopher who was brutally killed as a consequence of the fight for power between the pagan Hellenic faction and the emerging Christian sect which characterized that historical period. She is mentioned together with Aganice of Thessaly, Hildegard of Bingen, Catherina Hevelius and Maria Agnesi in the poem "Letter from Caroline Herschel" by Siv Cedering cited in the introduction, but as we can see from our list this represents just a limited sample.

In the early Middle Ages the social position of women within noble families remarkably improved, at least in certain aspects. The monasteries, especially, for a certain period represented remarkable cultural centers and environments where women in certain cases could be educated in every field. The most significant example of such a situation is Hildegard of Bingen. In the following, due to a setback in the sexist sense of the Christian Church, the female role was increasingly hampered and consequently became more and more marginal, so that when, at the beginning of the eleventh century, the first universities were established, women were immediately excluded and had to resort to forms of non-academic education. It is especially in this way that there developed the above mentioned form of partnership between men and women in which the former played the dominant role, with mostly theoretical knowledge, and the latter instead became their assistants with predominantly practical or secondary tasks.

In the sixteenth century new and revolutionary concepts were developed in astronomy, and also several female scientists took part in this enterprise, although at the same time "witch hunts" were storming in all Europe. Later, the seventeen and eighteenth centuries witnessed the appearance of a new phenomenon among the women of aristocracy, that of scientific circles or "salons" held by women for scientists and scholars. 


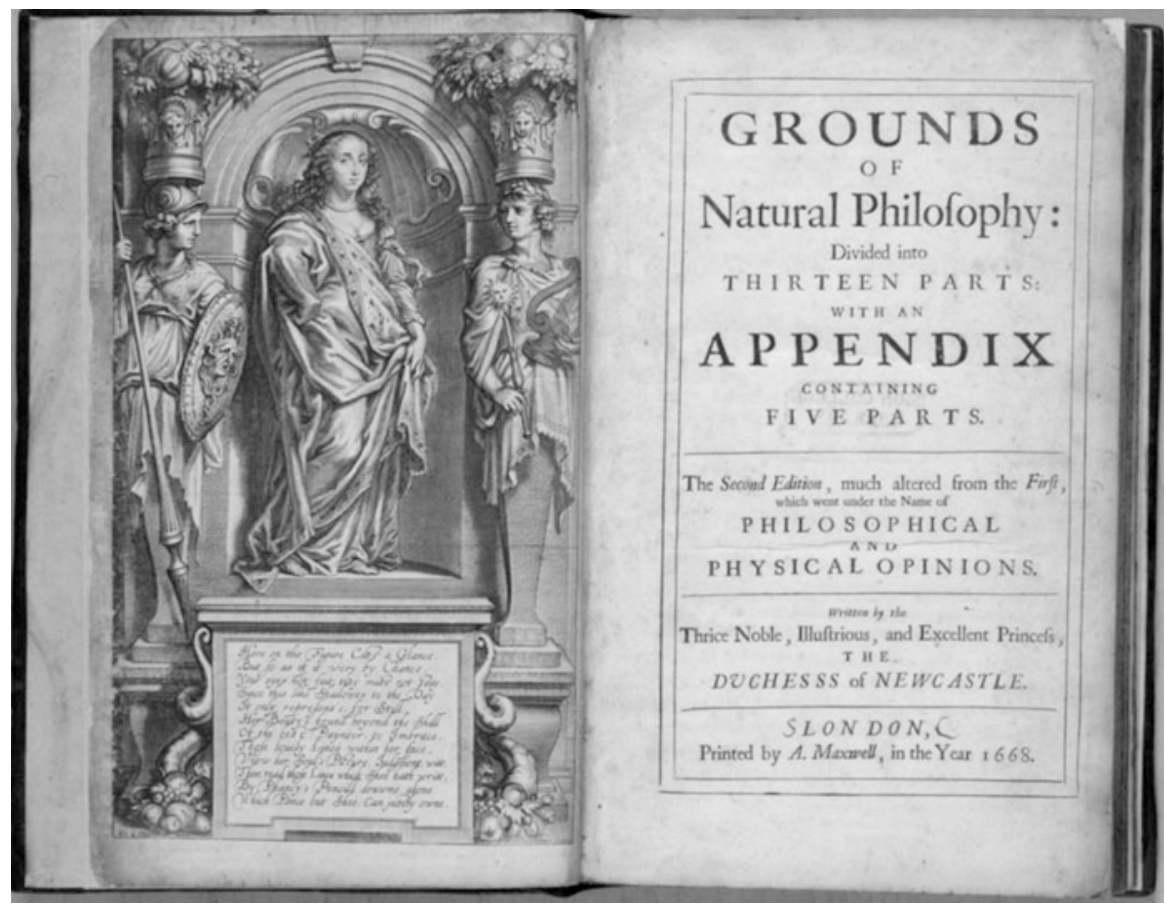

Title page and frontispiece from "Grounds of natural philosophy" by Margaret Cavendish, Duchess of Newcastle

Among the "dames of science" many prominent figures can be found, such as Margaret Cavendish (who financed the Royal Society and the Lucasian Chair of mathematics at Cambridge University, the place held by Newton), Lady Conway, Queen Christina of Sweden or the marquise du Châtelet. 


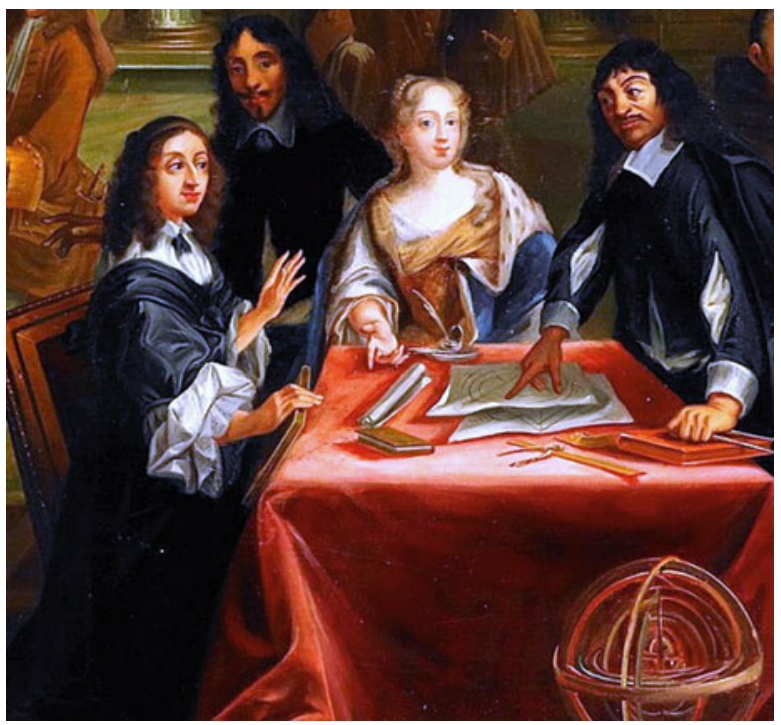

Queen Christina of Sweden (left) and René Descartes (right)

All of them distinguished themselves not only in the role of patroness, but also in that of scholars. Quite ironically, this phenomenon also contributed to the birth and development of the great scientific academies and societies, which, however, (at least the most prestigious ones) did not admit the presence of women until the twentieth century.

Opportunities were developed in relevant scientific research that emerged where innovative methodologies and techniques, especially in the world of crafts where women's skills could be exploited. Examples of this phenomenon include Elisabetha Koopman Hevelius and Elisabeth Maria Winkelmann Kirch, during the seventeenth century. The development of science made the equipment more and more complex, and when its costs exceeded those accessible to a personal and "homemade" or craft enterprise, the research shifted permanently within the Academic and male-dominated world. Similarly to what happened with the birth of the Universities or with the scientific societies, women were cut off from the official and most relevant scientific activity, and once more became reduced as ghost aides. Another reason that explains why several of them are unknown nowadays.

The modern era witnessed significant social changes, like emergence of a bourgeois social class and its values, which became prominent in society together with the importance of this new caste. However, their social canons relegated the women to a role of family management, and as a kind of "social showcase" whose prestige essentially depended on that of the man, to whom was exclusively reserved the leading and working roles. Women's education was not necessarily included in these social obligations. 



\section{Acknowledgments}

I want to thank Dr. Alberto Vecchiato from Astrophysical Observatory of Turin for giving us both his time and the benefit of his scientific, historical and languages knowledge. I am also grateful for the help of many librarians, archivists and their Italian and foreign institutions. 



\section{Contents}

\section{Part I Timelines from Enheduanna to Sonduk}

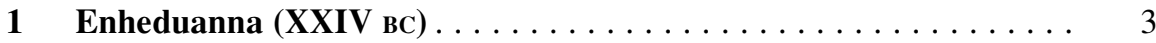

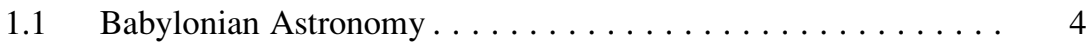

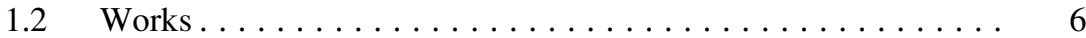

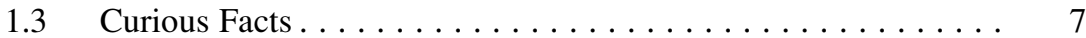

1.4 As They Said of Her................ 7

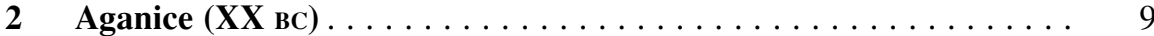

2.1 Astronomy and Mathematics in Ancient Egypt . . . . . . . . . . 11

2.2 Works . . . . . . . . . . . . . . . . . . . . . . . . . 14

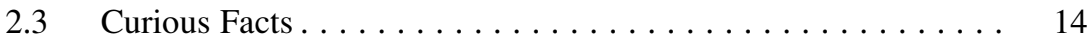

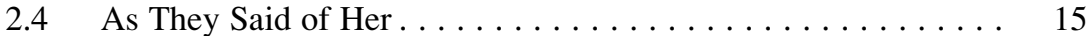

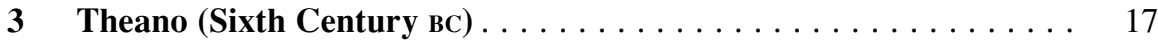

3.1 The Pythagorean School and Its Astronomy . . . . . . . . . . 18

3.2 Works ......................... 20

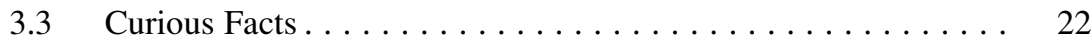

3.4 As They Say of Her.................. 22

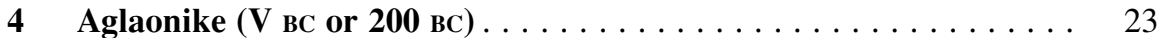

4.1 Greek Astronomy ...................... 24

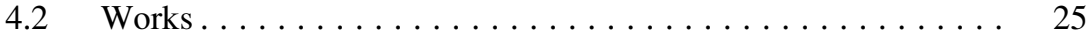

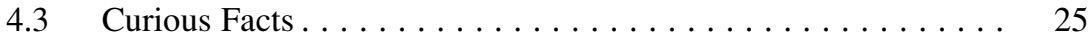

4.4 As They Said of Her................. 26

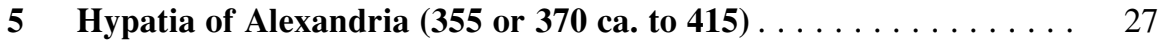

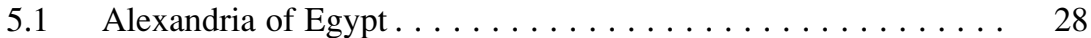

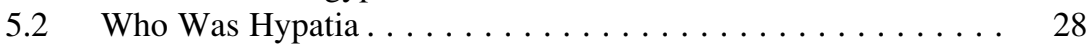

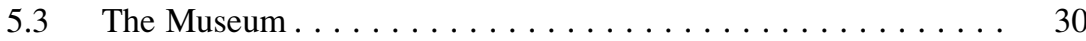

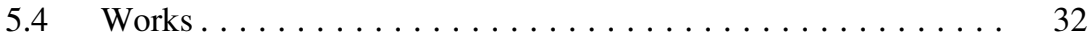




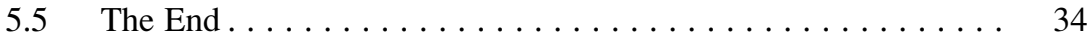

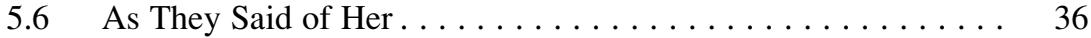

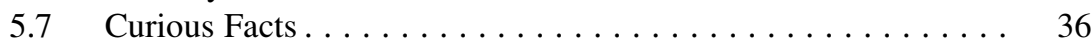

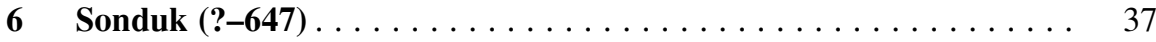

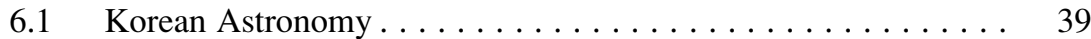

6.2 Works .......................... 40

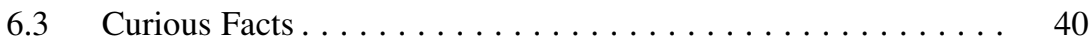

6.4 As They Said of Her.................. 41

\section{Part II Timelines from Fatima to Jeanne Dumée}

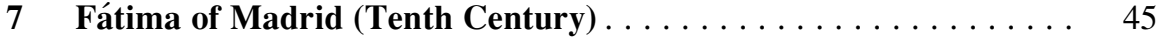

$7.1 \quad$ Arab and Islamic Astronomy . . . . . . . . . . . . . . . 45

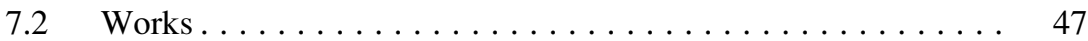

7.3 Curious Facts and as They Said of Her . . . . . . . . . 47

8 Hildegard von Bingen $(\mathbf{1 0 9 8}-1179) \ldots \ldots \ldots \ldots$

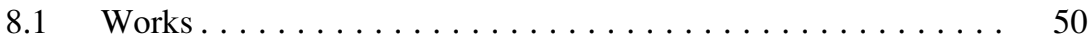

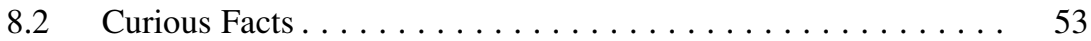

8.3 As They Said of Her. . . . . . . . . . . . . . . . 54

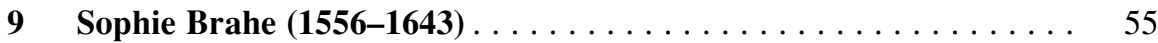

$9.1 \quad$ Works ....................... 57

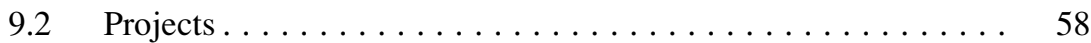

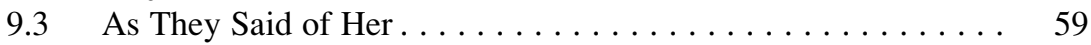

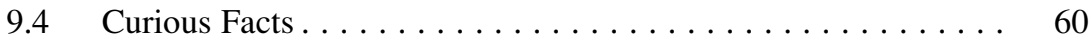

10 Maria Cunitz $(\mathbf{1 6 1 0}-1664) \ldots \ldots \ldots \ldots \ldots \ldots \ldots \ldots \ldots \ldots$

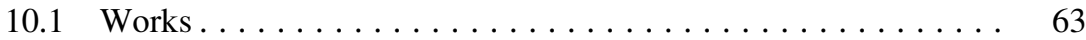

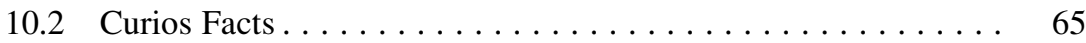

10.3 As They Said of Her. . . . . . . . . . . . . . 66

11 Elisabetha Catherina Koopman Hevelius (1647-1693) . . . . . . . 67

11.1 Works . . . . . . . . . . . . . . . . . . . . 69

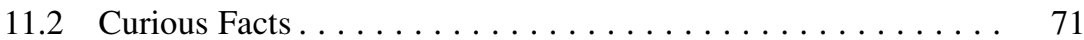

11.3 As They Said of Her. . . . . . . . . . . . . . 73

12 Jeanne Dumée $(\mathbf{1 6 6 0 - 1 7 0 6 )} \ldots \ldots \ldots \ldots \ldots \ldots \ldots \ldots \ldots$

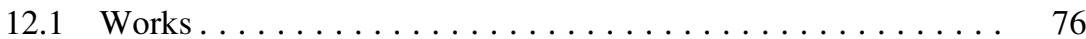

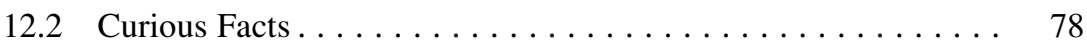

12.3 As They Said of Her and She Said of Herself . . . . . . . . . . 79

Part III Timelines from Maria Margarethe Winkelmann-Kirch to Nicole-Reine Étable de la Brière Lepaute

13 Maria Margarethe Winkelmann-Kirch (1670-1720) . . . . . . . . 83

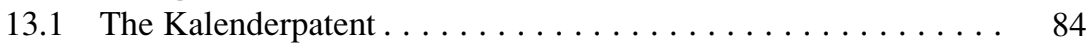

13.2 Discoveries and Works . . . . . . . . . . . 85 


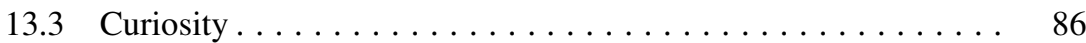

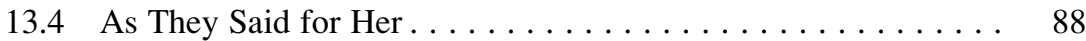

13.5 Awards........................ 88

14 Maddalena (1673-1744) and Teresa (1679-1767) Manfredi . . . . . 89

14.1 Works ........................... 92

14.2 Curious Facts . . . . . . . . . . . . . . . . . . 93

14.3 As They Said of Them .................. 94

15 Maria Clara Eimmart $(\mathbf{1 6 7 6}-1707) \ldots \ldots \ldots \ldots \ldots$

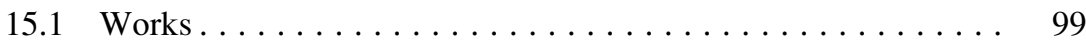

15.2 Curious Facts . . . . . . . . . . . . . . . 100

16 Christine (1696-1782) and Margaretha (1703-1744) Kirch . . . . . 103

16.1 Curios Facts . . . . . . . . . . . . . . . . . . . . . . . . . 103

16.2 Works . . . . . . . . . . . . . . . . . . . . . 104

16.3 The First Paid Woman Astronomer . . . . . . . . . . . . . . . . . 105

17 Gabrielle Émilie Le Tonnelier de Breteuil, marquise du Châtelet

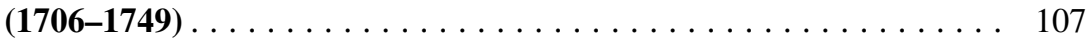

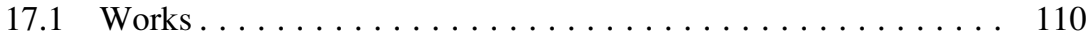

17.2 As They Said of Her . . . . . . . . . . . . . . . 113

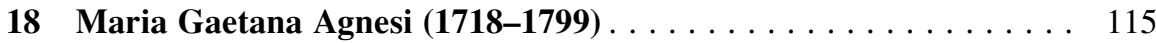

18.1 Works . . . . . . . . . . . . . . . . . . . . . . . 116

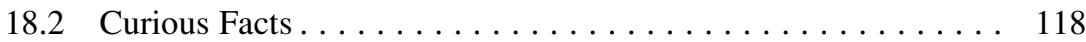

18.3 As They Said of Her . . . . . . . . . . . . . 120

19 Nicole-Reine Étable de la Brière Lepaute (1723-1788) . . . . . . . . . . 121

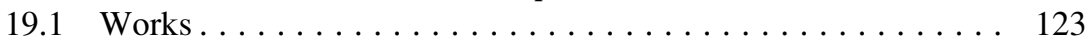

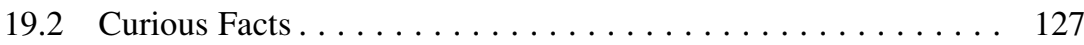

19.3 As They Said of Her . . . . . . . . . . . . . . . 127

Part IV Timelines from Louise Elisabeth Félicité Pourra de la Madeleine Du Piérry to Mary Fairfax-Somerville

20 Louise Elisabeth Félicité Pourra de la Madeleine Du Piérry

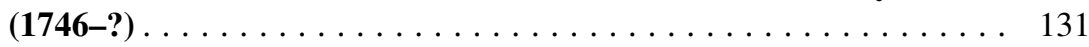

20.1 Works ............................. 132

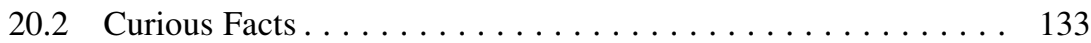

20.3 As They Said of Her. . . . . . . . . . . . . . . 134

21 Caroline Lucretia Herschel $(\mathbf{1 7 5 0}-1848) \ldots \ldots \ldots \ldots \ldots \ldots$

21.1 From Cinderella to Soprano . . . . . . . . . . . . . . . 136

21.2 Becoming a Professional Astronomer............... 139

21.3 Comet-Hunter . . . . . . . . . . . . . . . . . . . . . . 141

21.4 Assistant to the King's Astronomer. . . . . . . . . . . . . . . . . . . 143

21.5 Curiosity ....................... 145 
21.6 As They Said of Her . . . . . . . . . . . . . . . . . . . 147

21.7 Awards... . . . . . . . . . . . . . . . . . . . . . . 149

22 Margaret Bryan $(\mathbf{1 7 6 0 ? - 1 8 1 6 )} \ldots \ldots \ldots \ldots \ldots \ldots \ldots \ldots$

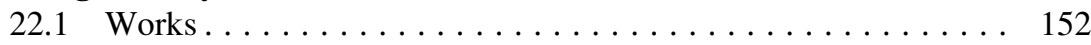

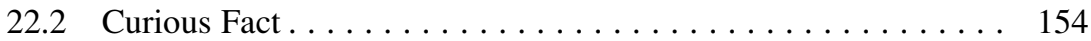

22.3 As They Said of Her . . . . . . . . . . . . . . 154

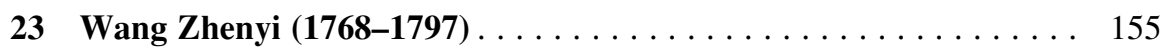

23.1 Works and Experiments . . . . . . . . . . . . 156

23.2 What She Wrote, as They Said for Her and What She Said . . . 157

23.3 Awards....................... 158

24 Marie-Jeanne Amélie Harlay Lefrancais de Lalande

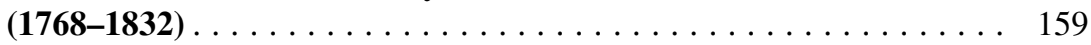

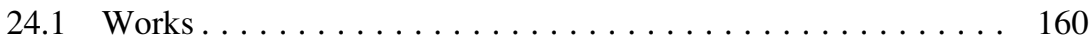

24.2 As They Said of Her. . . . . . . . . . . . . . . 161

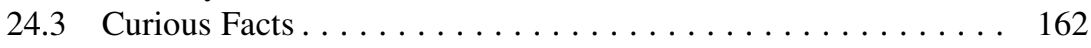

25 Mary Fairfax-Somerville $(\mathbf{1 7 8 0}-1872) \ldots \ldots \ldots \ldots \ldots$

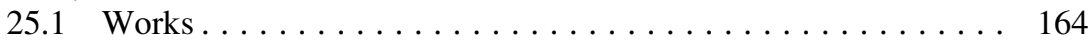

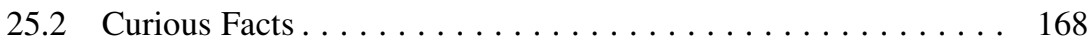

25.3 As They Said of Her . . . . . . . . . . . . 170

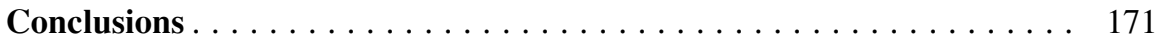

Bibliography . . . . . . . . . . . . . . . . . . . . . . 177 